\title{
Click-Type Pt"-Mediated Hydroxyguanidine-Nitrile Coupling Provides Useful Catalysts for Hydrosilylation Cross-Linking
}

\author{
Marina Ya. Demakova, Dmitrii S. Bolotin, Nadezhda A. Bokach, ${ }^{*}$ Regina M. Islamova, \\ Galina L. Starova, and Vadim Yu. Kukushkin*[a]
}

\begin{abstract}
The nitrile complexes trans- $\left[\mathrm{PtCl}_{2}(\mathrm{RCN})_{2}\right] \quad(\mathrm{R}=\mathrm{Et} \quad(\mathrm{NC} 1)$, $t \mathrm{Bu}$ (NC2), Ph (NC3), $\left.p-\mathrm{BrC}_{6} \mathrm{H}_{4}(\mathrm{NC4})\right)$ and cis- $\left[\mathrm{PtCl}_{2}(\mathrm{RCN})_{2}\right](\mathrm{R}=\mathrm{Et}$ (NC5), tBu (NC6), $\mathrm{Ph}(\mathrm{NC7}))$ react with 1 equiv of the hydroxyguanidine $\mathrm{OC}_{4} \mathrm{H}_{8} \mathrm{NC}(=\mathrm{NOH}) \mathrm{NH}_{2}(\mathrm{HG})$ furnishing the mono-addition products trans- and cis- $\left[\mathrm{PtCl} \mathrm{Cl}_{2}(\mathrm{RCN})\{\mathrm{NH}=\mathrm{C}(\mathrm{R}) \mathrm{ON}=\right.$ $\left.\mathrm{C}\left(\mathrm{NH}_{2}\right) \mathrm{NC}_{4} \mathrm{H}_{8} \mathrm{O}\right\}$ ] (1-4 and 9-11; 7 examples; $54-74 \%$ yield). Treatment of any of the nitrile complexes NC1-NC7 with HG in a 1:2 molar ratio generated the bis-addition products transand cis- $\left[\mathrm{PtCl}_{2}\left[\mathrm{NH}=\mathrm{C}(\mathrm{R}) \mathrm{ON}=\mathrm{C}\left(\mathrm{NH}_{2}\right) \mathrm{NC}_{4} \mathrm{H}_{8} \mathrm{O}\right\}_{2}\right]$ (5-8 and 12-14; 7 examples; $69-89 \%$ yield). The $\mathrm{Pt}^{\prime \prime}$-mediated coupling between nitrile ligands and HG proceeds substantially faster than the corresponding reactions involving amid- and ketoximes
\end{abstract}

and gives redox stable products under normal conditions. Complexes 1, $6.4 \mathrm{CH}_{2} \mathrm{Cl}_{2}, 7.4 \mathrm{CH}_{2} \mathrm{Cl}_{2}, 8 \cdot 2 \mathrm{CH}_{2} \mathrm{Cl}_{2}$, and $\mathrm{NC} 4$ were studied by $\mathrm{X}$-ray crystallography. Platinum(II) species 1-3, 10, 11, and especially 9, efficiently catalyze the hydrosilylation cross-linking of vinyl-terminated poly(dimethylsiloxane) and trimethylsilyl-terminated poly(dimethylsiloxane-co-ethylhydrosiloxane) giving high-quality thermally stable silicon resins with no structural defects. The usage of these platinum species as the catalysts does not require any inhibitors and, moreover, the complexes and their mixtures with vinyl- and trimethylsilylterminated polysiloxanes are shelf-stable in air.

\section{Introduction}

Hydrosilylation, ${ }^{[1]}$ that is the catalytic addition of silicon hydrides to multiple bonds, is widely applied in silicone industry, for example in the synthesis of organofunctional silanes and silicone polymers, and in the cross-linking of multifunctional silicone hydride polymers with multivinyl functional silicon polymers resulting in cured silicone compositions. ${ }^{[2]}$ Insofar as hydrosilylation is relevant to hydrogenation, in many instances it requires catalytic systems that are similar to those applied in hydrogenation and they are almost exclusively based on transition metal species. ${ }^{[2]}$ Of these catalysts, platinum complexes are the most widely applied in both the laboratory and in industry.

Platinum-catalyzed hydrosilylation was studied in detail for hydrosilanes and olefins as the reaction partners, and this reaction is usually described by the Chalk-Harrod mechanism or its modified versions. ${ }^{[2,3]}$ The mechanism involves the oxidative

[a] Dr. M. Ya. Demakova, Dr. D. S. Bolotin, Prof. N. A. Bokach,

Prof. R. M. Islamova, G. L. Starova, Prof. V. Yu. Kukushkin Institute of Chemistry, Saint Petersburg State University

Universitetskaya nab. 26, 199034 Saint Petersburg (Russian Federation) E-mail:kukushkin@VK2100.spb.edu

nadia-bokach@yandex.ru

$\square$ Supporting information for this article is available on the WWW under http://dx.doi.org/10.1002/cplu.201500327. This material includes X-ray crystallographic data in CIF format and tables of crystal data; characterization of complexes 1-14; X-ray determination data, molecular structures of NC4, $1,6.4 \mathrm{CH}_{2} \mathrm{Cl}_{2}$, and $8.2 \mathrm{CH}_{2} \mathrm{Cl}_{2}$; preparation of trans- $\left[\mathrm{PtCl}_{2}(p\right.$ $\left.\mathrm{BrC}_{6} \mathrm{H}_{4} \mathrm{CN}\right)_{2}$ ] (NC4); application of 1-3 and 9-11 as catalysts for hydrosilylation cross-linking of polysiloxanes; IR, ${ }^{1} \mathrm{H}$ and ${ }^{13} \mathrm{C}\left\{{ }^{1} \mathrm{H}\right\}$ NMR, and HRESI mass spectra of NC4 and 1-14. addition of silanes to a metal-bound alkene, an insertion of the alkene into the $\mathrm{Pt}-\mathrm{H}$ or $\mathrm{Pt}-\mathrm{SiR}_{3}$ bonds, and reductive elimination accompanied by $\mathrm{Si}-\mathrm{C}$ bond formation. Reported data on metal-catalyzed hydrosilylation cross-linking of vinyl polysiloxanes are rather limited.

Although the number of new catalysts for the hydrosilylation of vinyl polysiloxanes has substantially expanded in recent years, ${ }^{[1,4]}$ Karstedt's complex is the best established catalyst for the cross-linking. ${ }^{[2,3 b]}$ Its main disadvantages are associated with its high reactivity which makes the cross-linking unselective even at room temperature (RT). Consequently an inhibitor (e.g. maleates, fumarates, and $\beta$-alkynoles) ${ }^{[2]}$ is required, which in turn may impair the strength characteristics of the formed silicone formulations. ${ }^{[5]}$ In this context, the development of new efficient catalysts for the hydrosilylation cross-linking is challenging. These catalysts should be more selective, that is display controlled pot-life and curing time without inhibitors, they should be stable upon storage and under the cross-linking conditions, and they should tolerate various functional groups (hydroxyl, carbonyl, ester, etc.). In addition, the search for the new catalytic systems includes the design of catalysts that are shelf-stable at room temperature but start to act at higher temperatures as any premature curing would cause adherence of silicone polymers to machine parts (e.g. rollers) leading to frequent shutdown for cleaning.

Hence, exercising precise control of the catalytic activity for cross-linking requires a switchable precatalysis of the hydrosilylation, which can be triggered by, in particular, thermal activation. As the most efficient catalysts for hydrosilylation cross- 
linking are based on platinum(0) complexes (e.g., Karsted's catalyst), we decided to design platinum(II) complexes that are stable under normal conditions but are involved in redox upon heating, generating catalytically active low-valent platinum species. The idea included the synthesis of platinum(II) species functionalized with strong reducing groups that are attached by a spacer to the metal, which exhibits rather strong oxidation properties. This approach was quite successful when we synthesized acyclic carbene platinum(II) and palladium(II) complexes (for review see Ref. [6]); the carbene has reducing properties and we applied these species as hydrosilylation $^{[7]}$ and cross-coupling ${ }^{[8]}$ catalysts.

The main goals of this work were the following. Firstly, we were interested in the extension of platinum(II)-mediated oxime-nitrile coupling to hydroxyguanidines as we felt that this reaction should proceed as rapidly and efficiently as other click-type reactions. Secondly, we planned to explore the catalytic properties of newly synthesized compounds in hydrosilylation cross-linking of silicone polymers, namely vinyl-functionalized polysiloxanes with $\mathrm{SiH}$ functionalized oligosiloxanes.

\section{Results and Discussion}

\section{Synthesis of catalysts for hydrosilylation cross- linking}

Within the framework of our ongoing project on the metal-mediated reactions of nitrile substrates, ${ }^{\left[{ }^{[0]}\right.}$ we studied the addition of HON-type nucleophiles, specifically oximes, amidoximes, and hydroxylamines, to metal-activated nitriles and cyanamides, leading to amidines, ${ }^{[10]}$ amidrazones $_{,}{ }^{[11]}$ acylamides, ${ }^{[12]}$ 1,3,5-triazapentadienes, ${ }^{[13]}$ carboxamides, ${ }^{[14]}$ and related species ${ }^{[15]}$ such as phthalocyanines ${ }^{[16]}$ and 1,2,4-oxadiazoles. ${ }^{[17]}$ In particular, we found that a hydroxyguanidine in the presence of zinc(II) centers is a highly reactive nucleophile toward coupling with RCN compounds. ${ }^{[18]}$ Concurrently, it is well known that compounds featuring the guanidine group easily reduce $\mathrm{Pt}^{\text {Il }}$ centers generating metallic platinum. ${ }^{[19]}$ Our idea was to apply the fast and quantitative metalmediated nitrile-oxime coupling for the construction of $\mathrm{Pt}^{\prime \prime}$ complexes that bear a remote reductive group, thus giving a precatalyst for temperature-controlled hydrosilylation crosslinking.

As starting materials, we addressed, on the one hand, the platinum(II) nitrile complexes trans- $\left[\mathrm{PtCl}_{2}(\mathrm{RCN})_{2}\right](\mathrm{R}=\mathrm{Et}(\mathrm{NC1})$, $t \mathrm{Bu}$ (NC2), $\mathrm{Ph}$ (NC3), $p$ - $\mathrm{BrC}_{6} \mathrm{H}_{4}$ (NC4); Scheme 1) and cis$\left[\mathrm{PtCl}_{2}(\mathrm{RCN})_{2}\right](\mathrm{R}=\mathrm{Et}(\mathrm{NC5}), t \mathrm{Bu}$ (NC6, Ph (NC7); Scheme 2) and, on the other hand, the hydroxyguanidine compound $\mathrm{OC}_{4} \mathrm{H}_{8} \mathrm{NC}(=\mathrm{NOH}) \mathrm{NH}_{2}(\mathrm{HG})$ featuring a morpholino group that provides solubility in $\mathrm{CH}_{2} \mathrm{Cl}_{2}$. The reaction of $\mathrm{NC1}-\mathrm{NC7}$ with HG proceeds rapidly at room temperature at both 1:1 and 1:2 molar ratios and affords complexes bearing iminoacylated HG species (Schemes 1 and 2 and Table 1). Complexes NC1-NC7

\begin{tabular}{|llllll|}
\hline \multicolumn{5}{|c|}{ Table 1. Compound numbering and yields of the obtained species. } \\
Cmpd & $\mathrm{R}$ & Yield [\%] & Cmpd & $\mathrm{R}$ & Yield [\%] \\
\hline $\mathbf{1}$ & $\mathrm{Et}$ & 72 & $\mathbf{5}$ & $\mathrm{Et}$ & 89 \\
$\mathbf{2}$ & $t \mathrm{Bu}$ & 74 & $\mathbf{6}$ & $t \mathrm{Bu}$ & 78 \\
$\mathbf{3}$ & $\mathrm{Ph}$ & 67 & $\mathbf{7}$ & $\mathrm{Ph}$ & 81 \\
$\mathbf{4}$ & $p-\mathrm{BrC}_{6} \mathrm{H}_{4}$ & 73 & $\mathbf{8}$ & $p-\mathrm{BrC}_{6} \mathrm{H}_{4}$ & 69 \\
$\mathbf{9}$ & $\mathrm{Et}$ & 61 & $\mathbf{1 2}$ & $\mathrm{Et}$ & 73 \\
$\mathbf{1 0}$ & $t \mathrm{Bu}$ & 54 & 13 & $t \mathrm{Bu}$ & 89 \\
$\mathbf{1 1}$ & $\mathrm{Ph}$ & 67 & $\mathbf{1 4}$ & $\mathrm{Ph}$ & 78 \\
\hline
\end{tabular}

react with 1 equiv of $\mathbf{H G}$ in a dichloromethane solution at room temperature for 5-10 min. The mono-addition products 1-4 and 9-11 (7 examples) were isolated as pure compounds in $54-74 \%$ yield after column chromatography. Reaction of dichloromethane solution of NC1-NC7 with HG in a 1:2 molar ratio at room temperature for $2-6 \mathrm{~h}$ generated the bisaddition products 5-8 and 12-14 (7 examples).

The observed coupling is metal-mediated. Indeed, in the absence of platinum(II), the interaction between the nitriles and the hydroxyguanidine at room temperature was not detected. At $60-80^{\circ} \mathrm{C}$, we observed slow unselective decomposition of HG. Furthermore, HG decomposed completely and unselec- 
tively at $120^{\circ} \mathrm{C}$ in DMSO after $2 \mathrm{~d}$ giving a spectrum of products, whereas the starting nitriles in the mixture remain intact.

Previous work shows that the activation of aryl- and alkylcyanides by a platinum(II) center is insufficient for the nucleophilic addition of the ketoximes $\mathrm{R}_{2}^{\prime} \mathrm{C}=\mathrm{NOH}\left(\mathrm{R}_{2}^{\prime}=\mathrm{Me}_{2} ; \mathrm{C}_{4} \mathrm{H}_{8}\right)$. Only in the case of cis- $\left[\mathrm{Pt}\left(\mathrm{NCNR}_{2}\right)_{2}\left(\mathrm{PPh}_{3}\right)_{2}\right]^{2+}(\mathrm{R}=\mathrm{Me}$, Et) in the presence of $\mathrm{Ag}^{+}$or $\mathrm{Cu}^{2+}$, as additional activators, were the chelated mono-addition products obtained. ${ }^{[20]}$ Later, the platinum(II)-mediated reaction of oximes with RCN ligands was extended to electron-deficient nitriles featuring electron-withdrawing groups (i.e. $\mathrm{Ph}, \mathrm{CH}_{2} \mathrm{Cl}, \mathrm{CH}_{2} \mathrm{CO}_{2} \mathrm{Me}$ ); the reaction proceeds at $40-50{ }^{\circ} \mathrm{C}$ and/or under microwave treatment producing monodentately bound $\mathrm{O}$-iminoacylated oximes and these metal species were isolated in moderate yields. ${ }^{[21]}$ Recently, we observed that the nucleophilic addition of amidoximes to $\left[\mathrm{PtCl}_{2}(\mathrm{RCN})_{2}\right]$ species proceeds at room temperature and even at $-8^{\circ} \mathrm{C}$ to provide complexes bearing the iminoacylated species as ligands in good yields after a reaction time of $3 \mathrm{~h}$ for the mono-addition products and $24-48 \mathrm{~h}$ for the bis-addition products. ${ }^{\text {[22] }}$

In this work, we observed that the nucleophilic addition of hydroxyguanidine HG to the nitrile ligand in complexes NC1NC7 proceeds at room temperature and gives mono-addition products 1-4 and 9-11 (after $5 \mathrm{~min}$ ) and bis-addition products 5-8 and 12-14 (after 2-6 h) in good yields (54-89\%). These observations indicate that hydroxyguanidines $\mathrm{R}_{2} \mathrm{NC}\left(\mathrm{NH}_{2}\right)=\mathrm{NOH}$ featuring two strong + $M$ donors at oxime moiety are much more reactive than amidoximes $\mathrm{R}^{\prime} \mathrm{C}\left(\mathrm{NH}_{2}\right)=\mathrm{NOH}$ featuring one donor $\mathrm{NH}_{2}$ group, which, in turn, are more reactive than conventional oximes $\mathrm{R}_{2}{ }^{\prime} \mathrm{C}=\mathrm{NOH}\left(\mathrm{R}^{\prime \prime}=\mathrm{Alk}, \mathrm{Ar}\right)$ for the same reasons. The accumulating $+M$ effect makes HG quite a strong nucleophile that adds to nitriles weakly activated by the $\mathrm{Pt}^{\mathrm{II}}$ center and this facile reaction fulfils the requirements of the click reactions.

\section{Characterization of 1-14}

Complexes 1-14 give satisfactory $\mathrm{C}, \mathrm{H}$, and $\mathrm{N}$ elemental analyses for the proposed formulas, and these species were also characterized by high-resolution ESI mass spectrometry and by IR and ${ }^{1} \mathrm{H}$ and ${ }^{13} \mathrm{C}\left\{{ }^{1} \mathrm{H}\right\}$ NMR spectroscopy (for all spectra and detailed descriptions of the characterization see the Supporting Information). Bis-addition complexes 6-8 and mono-addition complex 1 were studied by $\mathrm{X}$-ray crystallography. All these complexes crystallized as the $\mathrm{CH}_{2} \mathrm{Cl}_{2}$ solvates, $6 \cdot 4 \mathrm{CH}_{2} \mathrm{Cl}_{2}$, $7 \cdot 4 \mathrm{CH}_{2} \mathrm{Cl}_{2}$, and $8 \cdot 2 \mathrm{CH}_{2} \mathrm{Cl}_{2}$, respectively; no solvent was observed in the crystal lattices of 1 (Figure 1 and Figures 1S-4S in the Supporting Information).

\section{Application of 1-3 and 9-11 as catalysts for hydrosilylation cross-linking of polysiloxanes}

In the framework of our project aimed at verifying the catalytic properties of platinum-group metal species in organic transformations (for major reviews from our group on this topic see Refs. $[6,23])$ we found that complexes $\mathbf{1 - 3}$ and $\mathbf{9 - 1 1}$ behave

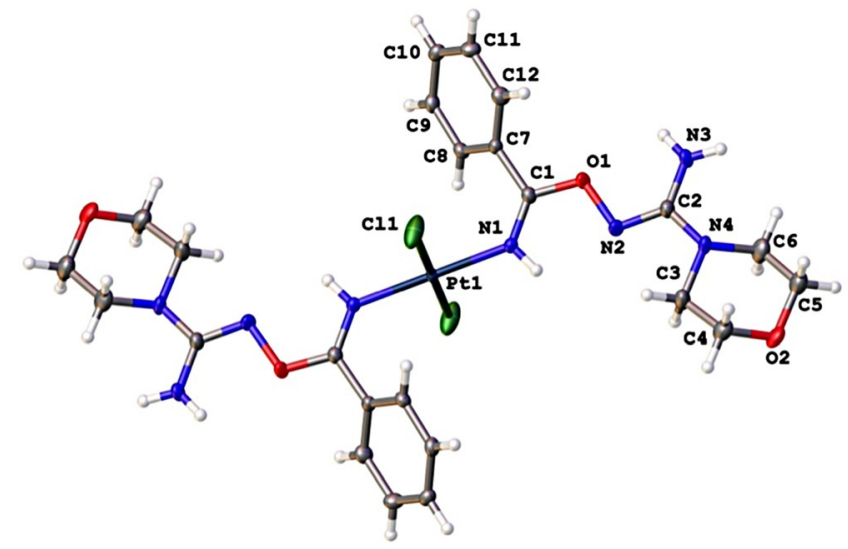

Figure 1. Molecular structure of $7 \cdot 4 \mathrm{CH}_{2} \mathrm{Cl}_{2}$ with the atomic numbering scheme; solvent molecules are omitted for simplicity. Thermal ellipsoids are given at the $50 \%$ probability level. Selected bond lengths $[\AA]$ and angles [ $\left.{ }^{\circ}\right]$ : Pt1-N1 2.006(2), N1-C1 1.275(4), O1-N2 1.458(3), N2-C2 1.308(4); Pt1-N1-C1 130.19(19), C1-O1-N2 111.6(2), N1-C1-O1 123.3(2).

as efficient catalysts for the hydrosilylation cross-linking of vinyl-terminated poly(dimethylsiloxane) (PDMS) and trimethylsilyl-terminated poly(dimethylsiloxane-co-ethylhydrosiloxane) (EHDMS) (Scheme 3).

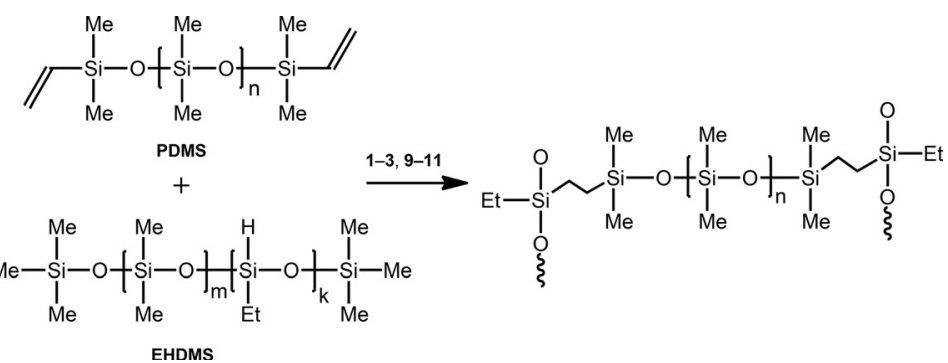

cheme 3. Platinum-catalyzed hydrosilylation cross-linking of siloxane polymers.

Because bis-addition products 5-8 and 12-14 and the mono-addition product 4 were not soluble in $\mathrm{CH}_{2} \mathrm{Cl}_{2}$ we could not test them as catalysts. The differential scanning calorimetry (DCS) curves of 9-11 used to monitor the cross-linking display exothermic peaks (Supporting Information, Figure 5S). Pot-life $\left(\tau_{\text {pot-life }}\right)$, curing time $\left(\tau_{\text {curing }}\right)$, average value of enthalpy $(\Delta H)$, and average peak temperature $\left(T_{\text {peak }}\right)$ are compiled in Table 2.

We found that catalytic behavior of 1-3, 10 and 11 is similar within the experimental error, but $\mathbf{9}$ is substantially more efficient. The optimized concentration of the studied platinum catalysts for the cross-linking at room temperature is $1.0 \times$ $10^{-3} \mathrm{molL}^{-1}$ for $1-3,10$ and 11 , whereas it is $1.0 \times 10^{-4} \mathrm{~mol} \mathrm{~L}^{-1}$ for $\mathbf{9}$. We assume that the curing times obtained for complex 9 is shorter because complexes 1-3, 10, and 11 display high thermal stability in the siloxanes mixture and consequently higher temperature is required for their activation during cross-linking.

The catalytic activity of 1-3 and 9-11 was compared to that of Karstedt's catalyst. Complex $\mathbf{9}$ at the same concentration as Karstedt's catalyst, $1.0 \times 10^{-5} \mathrm{~mol} \cdot \mathrm{L}^{-1}$, is not effective at room temperature $\left(\tau_{\text {pot-life }}=20 \mathrm{~h}\right.$ and curing takes $\left.6 \mathrm{~d}\right)$, but at $50^{\circ} \mathrm{C}$ 


\begin{tabular}{|c|c|c|c|c|c|c|c|}
\hline Cat. & $\begin{array}{l}c_{\mathrm{cat}} \\
{\left[\mathrm{molL}^{-1}\right]}\end{array}$ & $\begin{array}{l}\tau_{\text {pot-life }} \\
23^{\circ} \mathrm{C}\end{array}$ & $\begin{array}{l}\tau_{\text {curing }} \\
23^{\circ} \mathrm{C}\end{array}$ & $\begin{array}{l}\tau_{\text {curing }} \\
50^{\circ} \mathrm{C}\end{array}$ & $T_{\text {onset }}\left[{ }^{\circ} \mathrm{C}\right]$ & $\begin{array}{l}\text { DSC data } \\
T_{\text {peak }}\left[{ }^{\circ} \mathrm{C}\right]\end{array}$ & $-\Delta H\left[\mathrm{Jg}^{-1}\right]$ \\
\hline 1 & $1.0 \times 10^{-3}$ & $6 \mathrm{~h}$ & $7 d$ & - & - & - & - \\
\hline 2 & $1.0 \times 10^{-3}$ & $2 d$ & $9 \mathrm{~d}$ & - & - & - & - \\
\hline 3 & $1.0 \times 10^{-3}$ & $5 \mathrm{~d}$ & $10 \mathrm{~d}$ & - & - & - & - \\
\hline 9 & $1.0 \times 10^{-3}$ & $50 \mathrm{~min}$ & $8 \mathrm{~h}$ & $2 \mathrm{~h}$ & 59 & 70 & 4.8 \\
\hline 9 & $1.0 \times 10^{-4}$ & $90 \mathrm{~min}$ & $17 \mathrm{~h}$ & $6 \mathrm{~h}$ & 85 & 98 & 4.0 \\
\hline 9 & $1.0 \times 10^{-5}$ & $20 \mathrm{~h}$ & $7 d$ & $2 d$ & 162 & 177 & 4.4 \\
\hline 10 & $1.0 \times 10^{-3}$ & $28 \mathrm{~h}$ & $2 \mathrm{~d}$ & $9 \mathrm{~h}$ & 116 & 131 & 4.3 \\
\hline 11 & $1.0 \times 10^{-3}$ & $2 d$ & $8 d$ & $18 \mathrm{~h}$ & 124 & 129 & 4.5 \\
\hline $\begin{array}{l}\text { Karstedt's } \\
\text { catalyst }\end{array}$ & $1.0 \times 10^{-5}$ & $3 \mathrm{~min}$ & $6 \mathrm{~h}$ & - & 35 & 51 & 4.5 \\
\hline
\end{tabular}

the cross-linking involving 9 is complete after $6 \mathrm{~h}(1.0 \times$ $\left.10^{-4} \mathrm{~mol} \mathrm{~L}^{-1}\right)$ and $2 \mathrm{~d}\left(1.0 \times 10^{-5} \mathrm{~mol} \mathrm{~L}^{-1}\right)$. The enthalpy of the reaction catalyzed by $9-11\left(1.0 \times 10^{-3}-1.0 \times 10^{-5} \mathrm{~mol} \mathrm{~L}^{-1}\right)$ is well comparable to the $\Delta H$ value obtained for Karstedt's catalyst $\left(1.0 \times 10^{-5} \mathrm{~mol} \mathrm{~L}^{-1}\right)$. The catalytic activity of trans complexes $1-$ $3\left(1.0 \times 10^{-3} \mathrm{~mol} \mathrm{~L}^{-1}\right)$ for the hydrosilylation of vinyl polysiloxanes is significantly lower; that is $\tau_{\text {pot-life }}$ ranges from $6 \mathrm{~h}(\mathbf{1})$ to $5 \mathrm{~d}$ (3) and $\tau_{\text {curing }}$ ranges from 7 to $10 \mathrm{~d}$. The higher catalytic activity of $\mathbf{9}$ in comparison to that of the studied complexes $\mathbf{1 - 3}$, 10 , and 11 can be rationalized by its higher solubility in the silicon systems. In addition, owing to the rather low thermal stability of $\mathbf{9}$ in the silicon mixture, lower temperatures are required for its activation and, consequently, the cross-linking proceeds easily.

An obvious advantage of our catalysts is their solubility in $\mathrm{CH}_{2} \mathrm{Cl}_{2}$ where these species are stable in air at room temperature, whereas commercially available xylene solutions of Karstedt's catalyst should be handled and stored under inert atmosphere. Furthermore, mixtures of PDMS and 1-3 or 9-11 are also stable in air. Thus, curing tests and the DSC data indicate that the catalytic activity of the platinum complexes does not change for at least one month of storage in PDMS solutions. Silicone formulations obtained with 1-3 and 9-11 as the catalyst display no bubbles or other structural defects in contrast to those generated by application of Karstedt's catalyst without an added inhibitor.

To summarize, platinum complexes 1-3, 10, and 11 and especially 9 can be used as catalysts for the hydrosilylation crosslinking of siloxane polymers by reaction both at room temperature and $50^{\circ} \mathrm{C}$. They are stable compounds and their mixtures with PDMS are also stable even in air and, in addition, the catalytic application of 1-3 and 9-11 does not require inhibitors. The incorporation of a small amount of 1-3 and 9-11 (1.0x $10^{-5}, 1.0 \times 10^{-4}$, or $1.0 \times 10^{-3} \mathrm{~mol} \mathrm{~L}^{-1}$ ) in neat PDMS leads to a slight shift in the onset degradation temperature toward higher temperatures and increases the yield of the final residue (for the thermogravimetry (TG) curves see the Supporting Information). The data of tensile tests of the obtained silicon rubbers (Supporting Information, Table 3S) together with the TG data (Figures $6 \mathrm{~S}$ and $7 \mathrm{~S}$ and Table $2 \mathrm{~S}$ ) indicate the formation of networks with higher cross-linking density in the pres- ence of 9 in comparison to that of the rubbers obtained with Karstedt's catalyst. ${ }^{[2]}$

\section{Conclusion}

In the area of coordination chemistry, we observed the $\mathrm{Pt}^{\prime \prime}$-mediated coupling between nitriles and the hydroxyguanidine $\mathrm{OC}_{4} \mathrm{H}_{8} \mathrm{NC}(=\mathrm{NOH}) \mathrm{NH}_{2}$ and this integration proceeds faster than the relevant reactions involving amid- and ketoximes ${ }^{[9 a, b, 25]}$ and, moreover, as fast as required by click-methodologies (for recent reviews see Ref. [26]). This coupling can be employed for facile attachment of the guanidine moiety via a linker to metal species.

The specific feature of obtained complexes 1-14

is the availability of the remote guanidine moieties (that exhibit strong reducing properties ${ }^{[27]}$ ) and a distant platinum(II) center that, as a representative of the Noble metals family, behave as an oxidant. Previously attempted direct binding of guanidines to Pt" centers by coordination was always accompanied with redox giving metallic platinum. ${ }^{[19]}$ In our case, separation of the guanidine fragments and the platinum(II) center with the $\mathrm{HN}=\mathrm{C}-\mathrm{O}$ spacer led to redox stability of the formed complexes under normal conditions. However, redox between the guanidine and platinum(II) centers can be reached at higher temperatures leading presumably to lowvalent platinum species that are potentially active as catalysts for hydrosilylation cross-linking. ${ }^{[1 e, 2,28]}$

In the area of silicone polymer material chemistry, we developed new platinum(II)-based catalysts for cross-linking of silicone polymers. In particular, we observed that platinum(II) complexes $\mathbf{1 - 3}, \mathbf{1 0}-11$, and especially $\mathbf{9}$, efficiently catalyze the cross-linking of vinyl terminated poly(dimethylsiloxane) and trimethylsilyl terminated poly(dimethylsiloxane-co-ethylhydrosiloxane) giving high quality thermally stable silicon resins with no structural defects. Although 1-3 and 9-11 are less active than the widely used Karstedt's catalyst, application of 1-3 and 9-11 for the cross-linking can be performed not only at room temperature, but also, more efficiently, at $50^{\circ} \mathrm{C}$ which is crucial for some industrial applications. The latter is because stability of polysiloxane composition at room temperature and fast curing at higher temperatures allows the control of the hydrosilylation cross-linking via thermal activation of catalyst. This activation and conductance of the cross-linking at raising temperatures, in turn, allows avoiding adherence of silicone polymers at machine parts. ${ }^{[2]}$ The usage of these platinum species as the catalysts do not require any inhibitors and, moreover, the complexes and their mixtures with vinyl- and trimethylsilyl terminated polysiloxanes are shelf-stable in air and all these properties provide further benefits.

\section{Experimental Section}

Materials and Instrumentation: Solvents were obtained from commercial sources and used as received. Complexes trans- and

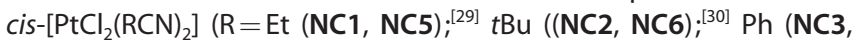
$\mathrm{NC7})^{[31]}$ ) were synthesized in accord with the published proce- 
dures; the trans and cis-isomers were separated by column chromatography on silica gel $\left(\mathrm{SiO}_{2}, 0.063-0.200 \mathrm{~mm}\right.$, Merck). For preparation and characterization (including $\mathrm{X}$-ray structure determination) of NC4 see the Supporting Information. The $\mathrm{N}$-morpholinecarbamidoxime was synthesized according to the literature method. ${ }^{[32]}$ Melting points were measured on a Stuart SMP30 apparatus in capillaries and are not corrected. TLC was performed on Merck $60 \mathrm{~F}_{254} \mathrm{SiO}_{2}$ plates. Microanalyses were carried out on a Euro EA3028-HT instrument. Electrospray ionization mass spectra were obtained on a Bruker micrOTOF spectrometer and maXis spectrometer equipped with an electrospray ionization (ESI) source. The instrument was operated in the positive-ion mode in the $\mathrm{m} / \mathrm{z}$ range 50-3000. The capillary voltage of the ion source was set at $-4500 \mathrm{~V}\left(\mathrm{ESI}^{+}-\mathrm{MS}\right)$. The nebulizer gas flow pressure was $0.4 \mathrm{bar}$ and the drying gas flow $4.0 \mathrm{Lmin}^{-1}$. For ESI, complexes were dissolved in $\mathrm{MeOH}$ or in $\mathrm{MeOH} / \mathrm{Me}_{2} \mathrm{SO}(1.00: 0.01, \mathrm{v} / \mathrm{v})$. In the isotopic pattern, the most intensive peak is reported. Infrared spectra $\left(4000-400 \mathrm{~cm}^{-1}\right)$ were recorded on a Shimadzu IR Prestige-21 instrument using $\mathrm{KBr}$ pellets. ${ }^{1} \mathrm{H}$ and ${ }^{13} \mathrm{C}\left\{{ }^{1} \mathrm{H}\right\}$ NMR spectra were measured on a Bruker Avance 400 spectrometer in $\mathrm{CDCl}_{3}, \mathrm{Me}_{2} \mathrm{CO}-d_{6}$, or $\mathrm{Me}_{2} \mathrm{SO}-d_{6}$ at ambient temperature; residual solvents signals were used as the internal standard. The progress of cross-linking was monitored by DSC using a NETZSCH DSC 204F1 Phoenix instrument. DSC conditions: cooling from 25 to $-10^{\circ} \mathrm{C}$, heating from -10 to $220^{\circ} \mathrm{C}$, and then cooling from 250 to $25^{\circ} \mathrm{C}\left(10^{\circ} \mathrm{Cmin}^{-1}\right)$; all components were mixed before the DSC studies and the DSC experiments were conducted twice for each test. TG measurements were performed on a NETZSCH TG 209F1 Libra instrument. Approximately $2 \mathrm{mg}$ of sample was placed in a platinum pan that was then heated from room temperature to $1000^{\circ} \mathrm{C}$ at $10^{\circ} \mathrm{C} \mathrm{min}^{-1}$ under flow of argon $\left(50 \mathrm{~mL} \mathrm{~min}^{-1}\right)$ or in air. Tensile tests (ISO 34) were performed on a Zwick Proline Z005 tensile testing machine and all experiments were carried out four times for each test.

X-ray crystal structure determinations: For the single-crystal Xray diffraction experiments crystals of all compounds were fixed on a micromount and placed on a Agilent Technologies Excalibur Eos diffractometer $\left(6.4 \mathrm{CH}_{2} \mathrm{Cl}_{2}, 7 \cdot 4 \mathrm{CH}_{2} \mathrm{Cl}_{2}\right.$, and $\left.8 \cdot 2 \mathrm{CH}_{2} \mathrm{Cl}_{2}\right)$ and were measured using monochromated $\mathrm{Mo}_{\mathrm{K} \alpha}$ radiation or placed on a Agilent Technologies SuperNova (Oxford Diffraction) diffractometer (NC4, 1) and measured using monochromated $\mathrm{Cu}_{\mathrm{k \alpha}}$ radiation. The crystals of $1,6.4 \mathrm{CH}_{2} \mathrm{Cl}_{2}, 7.4 \mathrm{CH}_{2} \mathrm{Cl}_{2}$, and $8.2 \mathrm{CH}_{2} \mathrm{Cl}_{2}$ were studied at $100 \mathrm{~K}$ and $\mathrm{NC} 4$ at $293 \mathrm{~K}$. The structures were solved by direct methods and refined by means of the SHELXL-97 program ${ }^{[33]}$ incorporated in the OLEX2 program package. ${ }^{[3]}$ The crystallographic data and some refinement parameters are given in Table S1. The carbon- and nitrogen-bound $\mathrm{H}$ atoms were placed in calculated positions and were included in the refinement in the "riding" model approximation, with $\mathrm{U}_{\text {iso }}(\mathrm{H})$ set to $1.5 \mathrm{U}_{e q}(\mathrm{C})$ and $\mathrm{C}-\mathrm{H} 0.96 \AA$ for the Me groups, $\mathrm{U}_{\text {iso }}(\mathrm{H})$ set to $1.2 \mathrm{U}_{e q}(\mathrm{C})$ and $\mathrm{C}-\mathrm{H} 0.97 \AA$ for the $\mathrm{CH}_{2}$ groups, and $\mathrm{U}_{\text {iso }}(\mathrm{H})$ set to $1.2 \mathrm{U}_{e q}(\mathrm{~N})$ and $\mathrm{N}-\mathrm{H} 0.86 \AA$ for the $\mathrm{NH}_{2}$ and $\mathrm{NH}$ groups. Empirical absorption corrections were applied in CrysAlisPro_ENREF_72 ${ }^{[35]}$ program complex using spherical harmonics implemented in the SCALE3 ABSPACK scaling algorithm. The crystals of $\mathbf{6}$ and $\mathbf{8}$ employed in the X-ray diffraction study underwent decomposition during the X-ray data collection and the obtained data, specifically the goodness-of-fit on $F^{2}$, are therefore far from perfect. CDC 1026389, 1419792, 1026393, 1026392, 1026391,1026388 contain the supplementary crystallographic data for this paper. These data can be obtained free of charge from the Cambridge Crystallographic Data Centre via www.ccdc.cam.ac.uk/ data request/cif.
Cross-linking catalytic tests: The polymers for evaluation of catalytic activity, vinyl-terminated polydimethylsiloxane (PDMS; $M_{\mathrm{w}}=$ $85800, M_{\mathrm{n}}=40500,0.5 \mathrm{wt} \%$ of $\left.-\mathrm{CH}=\mathrm{CH}_{2}\right)$ and trimethylsilyl-terminated poly(dimethylsiloxane-co-ethylhydrosiloxane) (EHDMS; $M_{\mathrm{w}}=$ 8150, $M_{\mathrm{n}}=4600,0.7 \mathrm{wt} \%$ of $\equiv \mathrm{Si}-\mathrm{H}$ ) were obtained from FSUE NIISK (Saint Petersburg, Russian Federation). $0.1 \mathrm{M}$ Karstedt's catalyst in vinyl-terminated polydimethylsiloxane (Aldrich) was used.

The cross-linking was studied in a system consisting of PDMS and EHDMS as cross-linking partners and a platinum catalyst, 1-3, 911 , or Karstedt's catalyst taken for comparison, at 20 or $50^{\circ} \mathrm{C}$. Standard formulation: [part $A] /[$ part $B]=1: 1$ ratio; concentration of 1-3, 9-11 was $1.0 \times 10^{-3} \mathrm{molL}^{-1}$ and concentration of 9 was $1.0 \times 10^{-3}$, $1.0 \times 10^{-4}$, or $1.0 \times 10^{-5} \mathrm{molL}^{-1}$. Part A: calculated amounts of $1-3$ and 9-11 (diluted in $50 \mu \mathrm{L} \mathrm{CH}_{2} \mathrm{Cl}_{2}$ ) were added to PDMS, the mixture was stirred and dried under vacuum at $30^{\circ} \mathrm{C}$ overnight to remove the solvent. Karsted's catalyst dissolved in vinyl-terminated polydimethylsiloxane was added to PDMS without drying in a vacuum. Part B: EHDMS $(10 \mathrm{~g})$ was added to PDMS $(50 \mathrm{~g})$ and this mixture was stirred until homogenization $\left(\left[-\mathrm{CH}=\mathrm{CH}_{2}\right] /[\equiv \mathrm{Si}-\right.$ $H]=1: 3$.

The cross-linking of the polysiloxanes mixture was performed in an aluminum vessel. The pot-life time was measured from the point of mixing equal amounts of Parts $A$ and $B$ before the viscosity of the initial mixture increases to unusable level at room temperature. Typically, the pot-life is defined as the time when viscosity of the catalyzed mixture has doubled. The curing time was measured from the point of mixing equal amounts of Parts $A$ and $B$ at room temperature or from the moment of placing the aluminum vessel with equal amounts of Parts $A$ and $B$ in a desiccator at $50^{\circ} \mathrm{C}$ until the liquid reaction mixture has transformed into a cured material.

\section{Synthetic Work}

Preparation of 1-4 and 9-11: A solution of $\mathrm{N}$-morpholinecarbamidoxime $(0.075 \mathrm{mmol})$ in dichloromethane $(1 \mathrm{~mL})$ was added dropwise to a vigorously stirred solution of NC1-NC7 $(0.075 \mathrm{mmol})$ in dichloromethane (2 mL for NC1-NC3, NC5-NC7; $5 \mathrm{~mL}$ for NC4) for $5 \mathrm{~min}$ at room temperature, whereupon the resulting solution was subjected to column chromatography on silica gel (eluent: chloroform/acetone $=10: 1, v / v)$. The first fraction was collected and the solvent was evaporated in vacuo at room temperature. The resulted crystalline residues were dried in air at room temperature.

1 (28.2 mg, $72 \%$ ): $R_{\mathrm{f}}=0.52$ (chloroform/acetone $=10: 1$, v/v); m.p. $124^{\circ} \mathrm{C}$ (decomp); ${ }^{1} \mathrm{H}$ NMR $\left(400 \mathrm{MHz}, \mathrm{CDCl}_{3}, 27^{\circ} \mathrm{C}\right): 7.72(\mathrm{~s}, \mathrm{br}, 1 \mathrm{H}$, $\mathrm{NH}), 4.46\left(\mathrm{~s}, \mathrm{br}, 2 \mathrm{H}, \mathrm{NH}_{2}\right), 3.78-3.73\left(\mathrm{~m}, 4 \mathrm{H}, \mathrm{CH}_{2}\right), 3.25-3.19(\mathrm{~m}, 4 \mathrm{H}$, $\left.\mathrm{CH}_{2}\right), 3.08\left(\mathrm{q}, 2 \mathrm{H}, \mathrm{CH}_{2}\right), 2.80\left(\mathrm{q}, 2 \mathrm{H}, \mathrm{CH}_{2}\right), 1.40\left(\mathrm{~m}, 6 \mathrm{H}, \mathrm{CH}_{3}\right) ;{ }^{13} \mathrm{C}\left\{{ }^{1} \mathrm{H}\right\}$ NMR $\left(100 \mathrm{MHz}, \mathrm{CDCl}_{3}, 27^{\circ} \mathrm{C}\right): 174.41(\mathrm{C}=\mathrm{NH}), 158.76(\mathrm{C}=\mathrm{N}), 117.36$ $(\mathrm{C} \equiv \mathrm{N}), 66.15\left(\mathrm{CH}_{2}\right), 45.75\left(\mathrm{CH}_{2}\right), 27.20\left(\mathrm{CH}_{2}\right), 12.83\left(\mathrm{CH}_{2}\right), 10.65,9.51$ $\left(\mathrm{CH}_{3}\right)$; IR $\left(\mathrm{KBr}\right.$, selected bonds, $\left.\mathrm{cm}^{-1}\right)$ : $\tilde{v}(\mathrm{~N}-\mathrm{H}): 3404(\mathrm{~s}), 3315(\mathrm{~s})$, 3188(s); $\tilde{v}(\mathrm{C}-\mathrm{H}): 2968(\mathrm{~m}), 2864(\mathrm{w}) ; \tilde{v}(\mathrm{C}=\mathrm{N}): 1627(\mathrm{~s}), 1569(\mathrm{~m}) ; \delta(\mathrm{C}-$ H): 775(w), 696(w); HRESI ${ }^{+}$-MS (MeOH): $\mathrm{m} / \mathrm{z}$ calcd for $\left([\mathrm{M}+\mathrm{Na}]^{+}\right)$: 544.0595; found: 544.0606; elemental analysis (\%) calcd for $\mathrm{C}_{11} \mathrm{H}_{21} \mathrm{~N}_{5} \mathrm{Cl}_{2} \mathrm{O}_{2} \mathrm{Pt}$ : C, 25.34; $\mathrm{H}, 4.06 ; \mathrm{N}, 13.43$; found: $\mathrm{C}, 25.74 ; \mathrm{H}$, 4.07; N, 13.51 .

2 (32.1 mg, 74\%): $R_{\mathrm{f}}=0.50$ (chloroform/acetone $=10: 1, \mathrm{v} / \mathrm{v}$ ); m.p. $136^{\circ} \mathrm{C}$ (decomp); ${ }^{1} \mathrm{H}$ NMR $\left(400 \mathrm{MHz}, \mathrm{CDCl}_{3}, 27^{\circ} \mathrm{C}\right): 8.23$ (s, br, $1 \mathrm{H}$, $\mathrm{NH}), 4.45\left(\mathrm{~s}, \mathrm{br}, 2 \mathrm{H}, \mathrm{NH}_{2}\right), 3.74-3.70\left(\mathrm{~m}, 4 \mathrm{H}, \mathrm{CH}_{2}\right), 3.25-3.23(\mathrm{~m}, 4 \mathrm{H}$, $\left.\left.\mathrm{CH}_{2}\right), 1.72\left(\mathrm{~s}, 9 \mathrm{H}, \mathrm{CH}_{3}\right), 1.46\left(\mathrm{~s}, 9 \mathrm{H}, \mathrm{CH}_{3}\right) ;{ }^{13} \mathrm{C}^{1} \mathrm{H}\right\}$ NMR $(100 \mathrm{MHz}$, $\left.\mathrm{CDCl}_{3}, 27^{\circ} \mathrm{C}\right): 172.27(\mathrm{C}=\mathrm{NH}), 154.99(\mathrm{C}=\mathrm{N}), 123.66(\mathrm{C} \equiv \mathrm{N}), 66.38$ $\left(\mathrm{CH}_{2}\right)$, $44.15\left(\mathrm{CH}_{2}\right), 30.22\left(\mathrm{C}\left(\mathrm{CH}_{3}\right)_{3}\right), 27.85\left(\mathrm{CH}_{3}\right)$; IR $(\mathrm{KBr}$, selected bonds, $\left.\mathrm{cm}^{-1}\right): \tilde{v}(\mathrm{~N}-\mathrm{H}): 3423(\mathrm{~s}), 3188(\mathrm{~m}) ; \tilde{v}(\mathrm{C}=\mathrm{N}), \delta(\mathrm{N}-\mathrm{H})$ : 1649(s), 
1573(m); $\delta(\mathrm{C}-\mathrm{H}):$ 685(m), 597(w); HRESI ${ }^{+}-\mathrm{MS}(\mathrm{MeOH}): \mathrm{m} / \mathrm{z}$ calcd for $\left([M-C l]^{+}\right)$: 542.1645; found: 542.1651; calcd for $\left([M+H]^{+}\right)$: 578.1645; found: 578.1405; elemental analysis (\%) calcd for $\mathrm{C}_{15} \mathrm{H}_{29} \mathrm{~N}_{5} \mathrm{Cl}_{2} \mathrm{O}_{2} \mathrm{Pt}$ : C, 31.20; $\mathrm{H}, 5.06 ; \mathrm{N}, 12.13$; found: $\mathrm{C}, 31.44 ; \mathrm{H}$, $5.10 ; \mathrm{N}, 11.90$.

$3(31.0 \mathrm{mg}, 67 \%): R_{\mathrm{f}}=0.44$ (chloroform/acetone $=10: 1, \mathrm{v} / \mathrm{v}$ ); m.p. $146^{\circ} \mathrm{C}$ (decomp); ${ }^{1} \mathrm{H}$ NMR $\left(400 \mathrm{MHz}, \mathrm{Me}_{2} \mathrm{SO}-d_{6}, 27^{\circ} \mathrm{C}\right.$ ): 8.04 (s, br, $1 \mathrm{H}, \mathrm{NH}) ; 7.85(\mathrm{~d}, 2 \mathrm{H}, \mathrm{Ph}), 7.75-7.71(\mathrm{~m}, 1 \mathrm{H}, \mathrm{Ph}), 7.63-7.59(\mathrm{~m}, 2 \mathrm{H}$, $\mathrm{Ph}), 7.42-7.34(\mathrm{~m}, 5 \mathrm{H}, \mathrm{Ph}), 5.76\left(\mathrm{~s}, \mathrm{br}, 2 \mathrm{H}, \mathrm{NH}_{2}\right), 3.70-3.68(\mathrm{~m}, 4 \mathrm{H}$, $\left.\left.\mathrm{CH}_{2}\right), 3.26-3.24\left(\mathrm{~m}, 4 \mathrm{H}, \mathrm{CH}_{2}\right) ;{ }^{13} \mathrm{C}^{1} \mathrm{H}\right\}$ NMR $\left(100 \mathrm{MHz}, \mathrm{Me}_{2} \mathrm{SO}-d_{6 \prime}\right.$ $\left.27^{\circ} \mathrm{C}\right): 170.91(\mathrm{C}=\mathrm{NH}), 149.47(\mathrm{C}=\mathrm{N}), 133.82,132.63,130.02,129.52$, 128.55, $128.04\left(\mathrm{CH}_{\mathrm{Ar}}\right), 119.39(\mathrm{C} \equiv \mathrm{N}), 111.18\left(\mathrm{C}_{\mathrm{Ar}}\right), 65.10\left(\mathrm{CH}_{2}\right), 44.62$ $\left(\mathrm{CH}_{2}\right)$; IR $\left(\mathrm{KBr}\right.$, selected bonds, $\left.\mathrm{cm}^{-1}\right): \tilde{v}(\mathrm{~N}-\mathrm{H}): 3419(\mathrm{~s}), 3332(\mathrm{~m})$, $3230(\mathrm{~m}) ; \tilde{v}(\mathrm{C}=\mathrm{N})$ and/or $\tilde{v}\left(\mathrm{C}=\mathrm{C}_{\mathrm{Ar}}\right)$ : $1627(\mathrm{~s}) ; \delta(\mathrm{N}-\mathrm{H}), \tilde{v}(\mathrm{C}=\mathrm{N})$, and/or $\tilde{v}\left(\mathrm{C}=\mathrm{C}_{\mathrm{Ar}_{\mathrm{r}}}\right): 1568(\mathrm{~m}) ; \delta(\mathrm{C}-\mathrm{H}): 852(\mathrm{~W}), 717(\mathrm{~m}) ; \mathrm{HRESI}{ }^{+}-\mathrm{MS}(\mathrm{MeOH}): \mathrm{m} / \mathrm{z}$ calcd for $\left([\mathrm{M}+\mathrm{H}]^{+}\right)$: 618.0779; found: 618.0764; elemental analysis (\%) calcd for $\mathrm{C}_{19} \mathrm{H}_{21} \mathrm{~N}_{5} \mathrm{Cl}_{2} \mathrm{O}_{2} \mathrm{Pt}$ : $\mathrm{C}, 36.96 ; \mathrm{H}, 3.43 ; \mathrm{N}, 11.34$; found: $\mathrm{C}$, $36.94 ; \mathrm{H}, 3.47 ; \mathrm{N}, 11.45$.

$4(42.4 \mathrm{mg}, 73 \%): R_{\mathrm{f}}=0.66$ (chloroform/acetone $=10: 1, \mathrm{v} / \mathrm{v}$ ), m.p. $140^{\circ} \mathrm{C}$ (decomp); ${ }^{1} \mathrm{H}$ NMR $\left(400 \mathrm{MHz}, \mathrm{CDCl}_{3}, 27^{\circ} \mathrm{C}\right): 8.45$ (d, $2 \mathrm{H}$, $\left.\mathrm{CH}_{\mathrm{Ar}}\right) ; 8.21(\mathrm{~s}, 1 \mathrm{H}, \mathrm{NH}) ; 7.74-7.68\left(\mathrm{~m}, 4 \mathrm{H}, \mathrm{CH}_{\mathrm{Ar}}\right), 7.60\left(\mathrm{~d}, 2 \mathrm{H}, \mathrm{CH}_{\mathrm{Ar}}\right)$; $4.62\left(\mathrm{~s}, 2 \mathrm{H}, \mathrm{NH}_{2}\right), 3.78-3.75\left(\mathrm{~m}, 4 \mathrm{H}, \mathrm{CH}_{2}\right), 3.29-3.26\left(\mathrm{~m}, 4 \mathrm{H}, \mathrm{CH}_{2}\right)$; ${ }^{13} \mathrm{C}\left\{{ }^{1} \mathrm{H}\right\}$ NMR $\left(100 \mathrm{MHz}, \mathrm{CDCl}_{3}, 27^{\circ} \mathrm{C}\right): 167.71(\mathrm{C}=\mathrm{NH}), 158.62(\mathrm{C}=\mathrm{N})$, $134.53,132.92,131.61,130.87\left(\mathrm{CH}_{\mathrm{Ar}}\right), 130.48,128.42,127.47\left(\mathrm{C}_{\mathrm{Ar}_{\mathrm{r}}}\right)$, $115.63(C \equiv \mathrm{N}), 108.70\left(C_{\mathrm{Ar}}\right), 65.92\left(\mathrm{CH}_{2}\right), 45.88\left(\mathrm{CH}_{2}\right) ; \mathrm{IR}(\mathrm{KBr}$, selected bonds, $\left.\mathrm{cm}^{-1}\right): \tilde{v}(\mathrm{~N}-\mathrm{H})$ : 3452(s), 3342(s), 3245(s); $\tilde{v}(\mathrm{C}-\mathrm{H}): 2854(\mathrm{w})$; $\tilde{v}(\mathrm{C}=\mathrm{N}): 1618(\mathrm{~s}) ; \delta(\mathrm{N}-\mathrm{H}), v(\mathrm{C}=\mathrm{N})$, and/or $\tilde{v}\left(\mathrm{C}=\mathrm{C}_{\mathrm{Ar}}\right): 1566(\mathrm{~m}) ; \delta(\mathrm{C}-\mathrm{H})$ : $858(\mathrm{w}), 721(\mathrm{~m}) ; \mathrm{HRESI}^{+}-\mathrm{MS}(\mathrm{MeOH}): \mathrm{m} / \mathrm{z}$ calcd for $\left([\mathrm{M}+\mathrm{H}]^{+}\right)$: 718.8986; found: 718.8980; elemental analysis (\%) calcd for $\mathrm{C}_{19} \mathrm{H}_{19} \mathrm{~N}_{5} \mathrm{Br}_{2} \mathrm{Cl}_{2} \mathrm{O}_{2} \mathrm{Pt}: \mathrm{C}, 29.44 ; \mathrm{H}, 2.47 ; \mathrm{N}, 9.03$; found: $\mathrm{C}, 29.71 ; \mathrm{H}$, $2.52 ; \mathrm{N}, 9.15$.

$9(23.8 \mathrm{mg}, 61 \%): R_{\mathrm{f}}=0.35$ (chloroform/acetone $=5: 1, \mathrm{v} / \mathrm{v}$ ); m.p. $120^{\circ} \mathrm{C}$ (decomp); ${ }^{1} \mathrm{H}$ NMR $\left(400 \mathrm{MHz}, \mathrm{CDCl}_{3}, 27^{\circ} \mathrm{C}\right): 7.76$ (s, br, $1 \mathrm{H}$, $\mathrm{NH}), 4.50\left(\mathrm{~s}, \mathrm{br}, 2 \mathrm{H}, \mathrm{NH}_{2}\right), 3.75-3.73\left(\mathrm{~m}, 4 \mathrm{H}, \mathrm{CH}_{2}\right), 3.23-3.21(\mathrm{~m}, 4 \mathrm{H}$, $\left.\mathrm{CH}_{2}\right), 3.07\left(\mathrm{q}, 2 \mathrm{H}, \mathrm{CH}_{2}\right), 2.79\left(\mathrm{q}, 2 \mathrm{H}, \mathrm{CH}_{2}\right), 1.42-1.39\left(\mathrm{~m}, 6 \mathrm{H}, \mathrm{CH}_{3}\right)$; ${ }^{13} \mathrm{C}\left\{{ }^{1} \mathrm{H}\right\}$ NMR $\left(100 \mathrm{MHz}, \mathrm{CDCl}_{3}, 27^{\circ} \mathrm{C}\right): 174.06(\mathrm{C}=\mathrm{NH}), 158.22(\mathrm{C}=\mathrm{N})$, $118.74(\mathrm{C} \equiv \mathrm{N}), 66.12\left(\mathrm{CH}_{2}\right), 45.99\left(\mathrm{CH}_{2}\right), 27.12,12.48\left(\mathrm{CH}_{2}\right), 10.39$, $9.03\left(\mathrm{CH}_{3}\right)$; IR ( $\mathrm{KBr}$, selected bonds, $\left.\mathrm{cm}^{-1}\right): \tilde{v}(\mathrm{~N}-\mathrm{H})$ : $3400(\mathrm{~s}), 3315(\mathrm{~s})$; $\tilde{v}(\mathrm{C}-\mathrm{H}): 3211(\mathrm{w}) ; \tilde{v}(\mathrm{C}=\mathrm{N}): 1631(\mathrm{~s}) ; \delta(\mathrm{N}-\mathrm{H}), \tilde{v}(\mathrm{C}=\mathrm{N}): 1570(\mathrm{~m}) ; \delta(\mathrm{C}-\mathrm{H})$ : 714(m), 588(w); HRESI ${ }^{+}-\mathrm{MS}(\mathrm{MeOH}): \mathrm{m} / \mathrm{z}$ calcd for $\left([\mathrm{M}+\mathrm{Na}]^{+}\right)$: 544.0595; found: 544.0606; elemental analysis (\%) calcd for $\mathrm{C}_{11} \mathrm{H}_{21} \mathrm{~N}_{5} \mathrm{Cl}_{2} \mathrm{O}_{2}$ Pt: $\mathrm{C}, 25.34 ; \mathrm{H}, 4.06 ; \mathrm{N}, 13.43$; found: $\mathrm{C}, 25.28 ; \mathrm{H}$, 4.02; N, 13.41 .

$10(23.4 \mathrm{mg}, 54 \%): R_{\mathrm{f}}=0.47$ (chloroform/acetone $\left.=5: 1, \mathrm{v} / \mathrm{v}\right) ;$ m.p. $128^{\circ} \mathrm{C}$ (decomp); ${ }^{1} \mathrm{H}$ NMR $\left(400 \mathrm{MHz}, \mathrm{CDCl}_{3}, 27^{\circ} \mathrm{C}\right): 8.68$ (s, br, $1 \mathrm{H}$, $\mathrm{NH}), 4.83\left(\mathrm{~s}, \mathrm{br}, 2 \mathrm{H}, \mathrm{NH}_{2}\right), 4.16-4.13\left(\mathrm{~m}, 4 \mathrm{H}, \mathrm{CH}_{2}\right), 3.63-3.60(\mathrm{~m}, 4 \mathrm{H}$, $\left.\left.\mathrm{CH}_{2}\right), 2.10\left(\mathrm{~s}, 9 \mathrm{H}, \mathrm{CH}_{3}\right), 1.83\left(\mathrm{~s}, 9 \mathrm{H}, \mathrm{CH}_{3}\right) ;{ }^{13} \mathrm{C}^{1} \mathrm{H}\right\}$ NMR $(100 \mathrm{MHz}$, $\left.\mathrm{CDCl}_{3}, 27^{\circ} \mathrm{C}\right): 168.10(\mathrm{C}=\mathrm{NH}), 154.39(\mathrm{C}=\mathrm{N}), 123.29(\mathrm{C} \equiv \mathrm{N}), 66.76$ $\left(\mathrm{CH}_{2}\right), 43.53\left(\mathrm{CH}_{2}\right), 27.22\left(\mathrm{CH}_{3}\right)$; IR $\left(\mathrm{KBr}\right.$, selected bonds, $\left.\mathrm{cm}^{-1}\right): \tilde{v}(\mathrm{~N}-$ $\mathrm{H}): 3438(\mathrm{~s}), 3350(\mathrm{~m}), 3280(\mathrm{~m}) ; \tilde{v}(\mathrm{C}-\mathrm{H}): 2920(\mathrm{~m}) ; \tilde{v}(\mathrm{C}=\mathrm{N}): 1627(\mathrm{~s})$; $\delta(\mathrm{N}-\mathrm{H}), \tilde{v}(\mathrm{C}=\mathrm{N}): 1571(\mathrm{~m}) ; \delta(\mathrm{C}-\mathrm{H}): 823(\mathrm{~m}), 713(\mathrm{w}), 551(\mathrm{w}) ; \mathrm{HRESI}^{+}$ -MS (MeOH): $\mathrm{m} / \mathrm{z}$ calcd for $\left([\mathrm{M}-\mathrm{Cl}]^{+}\right): 542.1645$; found: 542.1652 ; calcd for $\left([\mathrm{M}+\mathrm{H}]^{+}\right)$: 578.1403; found: 578.1408; elemental analysis (\%) calcd for $\mathrm{C}_{15} \mathrm{H}_{29} \mathrm{~N}_{5} \mathrm{Cl}_{2} \mathrm{O}_{2} \mathrm{Pt}$ : C, 31.20; $\mathrm{H}, 5.06 ; \mathrm{N}, 12.13$; found: $\mathrm{C}$, $31.38 ; \mathrm{H}, 5.14 ; \mathrm{N}, 12.20$.

11 (31.1 mg, 67\%): $R_{\mathrm{f}}=0.42$ (chloroform/acetone $=5: 1, \mathrm{v} / \mathrm{v}$ ); m.p. $142^{\circ} \mathrm{C}$ (decomp); ${ }^{1} \mathrm{H}$ NMR $\left(400 \mathrm{MHz}, \mathrm{CDCl}_{3}, 27^{\circ} \mathrm{C}\right): 8.55(\mathrm{~s}, \mathrm{br}, 1 \mathrm{H}$, $\mathrm{NH}), 7.81-7.72(\mathrm{~m}, 5 \mathrm{H}, \mathrm{Ph}), 7.62(\mathrm{~d}, 2 \mathrm{H}, \mathrm{Ph}), 7.52-7.40(\mathrm{~m}, 1 \mathrm{H}, \mathrm{Ph})$, 7.38-7.35 (m, 2H, Ph), $5.58\left(\mathrm{~s}, \mathrm{br}, 2 \mathrm{H}, \mathrm{NH}_{2}\right), 4.04-4.02\left(\mathrm{~m}, 4 \mathrm{H}, \mathrm{CH}_{2}\right)$, 3.55-3.52 (m, 4H, CH $\left.) ;{ }^{13} \mathrm{C}^{1} \mathrm{H}\right\}$ NMR $\left(100 \mathrm{MHz}, \mathrm{CDCl}_{3}, 27^{\circ} \mathrm{C}\right): 171.54$ $(C=\mathrm{NH}), 150.85(C=\mathrm{N}), 133.23,132.17,129.91,129.11,128.64,128.00$
$\left(\mathrm{CH}_{\mathrm{Ar}}\right), 120.12(\mathrm{C} \equiv \mathrm{N}), 111.69\left(\mathrm{C}_{\mathrm{Ar}}\right), 66.09\left(\mathrm{CH}_{2}\right), 45.73\left(\mathrm{CH}_{2}\right)$; IR $(\mathrm{KBr}$, selected bonds, $\left.\mathrm{cm}^{-1}\right): \tilde{v}(\mathrm{~N}-\mathrm{H}): 3498(\mathrm{~s}), 3326(\mathrm{~s}), 3230(\mathrm{~m}) ; \tilde{v}(\mathrm{C}-\mathrm{H})$ : 2972(m); $\tilde{v}(\mathrm{C}=\mathrm{N})$ and/or $\tilde{v}\left(\mathrm{C}=\mathrm{C}_{\mathrm{Ar}}\right): 1614(\mathrm{~s}) ; \delta(\mathrm{N}-\mathrm{H}), \tilde{v}(\mathrm{C}=\mathrm{N})$, and/or $\tilde{v}\left(\mathrm{C}=\mathrm{C}_{\mathrm{Ar}}\right): 1571(\mathrm{~m}) ; \delta(\mathrm{C}-\mathrm{H}): 867(\mathrm{w}), 727(\mathrm{w}) ; \mathrm{HRESI}^{+}-\mathrm{MS}(\mathrm{MeOH}): \mathrm{m} / \mathrm{z}$ calcd for $\left([\mathrm{M}+\mathrm{H}]^{+}\right)$: 618.0779; found: 618.0764; elemental analysis (\%) calcd for $\mathrm{C}_{19} \mathrm{H}_{21} \mathrm{~N}_{5} \mathrm{Cl}_{2} \mathrm{O}_{2} \mathrm{Pt}$ : C, 36.96; $\mathrm{H}, 3.43 ; \mathrm{N}, 11.34$; found: $\mathrm{C}$, $37.00 ; \mathrm{H}, 3.41 ; \mathrm{N}, 11.25$.

Preparation of 5-8 and 12-14: A solution of $\mathrm{N}$-morpholinecarbamidoxime $(0.100 \mathrm{mmol})$ in dichloromethane $(1 \mathrm{~mL})$ was added to a solution of NC1-NC7 $(0.050 \mathrm{mmol})$ in dichloromethane $(2 \mathrm{~mL}$ for NC1-NC3, NC5-NC7; $5 \mathrm{~mL}$ for NC4) at room temperature. Precipitates were released after 2-6 $\mathrm{h}$, whereupon they were separated by centrifugation, washed with dichloromethane (two $2 \mathrm{~mL}$ portions), and dried in air at room temperature.

5 (29.7 mg, 89\%): m.p. $134^{\circ} \mathrm{C}$ (decomp); ${ }^{1} \mathrm{H}$ NMR (400 MHz, $\mathrm{Me}_{2} \mathrm{SO}-$ $\left.d_{6}, 27^{\circ} \mathrm{C}\right): 8.24(\mathrm{~s}, 1 \mathrm{H}, \mathrm{NH}), 7.57(\mathrm{~s}, 1 \mathrm{H}, \mathrm{NH}), 6.38\left(\mathrm{~m}, 4 \mathrm{H}, \mathrm{NH}_{2}\right), 3.63-$ $3.60\left(\mathrm{~m}, 8 \mathrm{H}, \mathrm{CH}_{2}\right), 3.25-3.21\left(\mathrm{~m}, 4 \mathrm{H}, \mathrm{CH}_{2}\right), 3.16-3.13\left(\mathrm{~m}, 4 \mathrm{H}, \mathrm{CH}_{2}\right)$, 2.94-2.91 (m, 4H, CH $), 1.33-1.28\left(\mathrm{~m}, 6 \mathrm{H}, \mathrm{CH}_{3}\right) ;{ }^{13} \mathrm{C}\left\{{ }^{1} \mathrm{H}\right\} \quad \mathrm{HMR}$ $\left(100 \mathrm{MHz}, \mathrm{Me}_{2} \mathrm{SO}-d_{6}, 27^{\circ} \mathrm{C}\right): 175.01(\mathrm{C}=\mathrm{NH}), 160.00(\mathrm{C}=\mathrm{N}), 66.06$ $\left(\mathrm{CH}_{2}\right), 45.96\left(\mathrm{CH}_{2}\right), 27.93,11.15\left(\mathrm{CH}_{2}\right), 10.37\left(\mathrm{CH}_{3}\right)$; IR $(\mathrm{KBr}$, selected bonds, $\left.\mathrm{cm}^{-1}\right): \tilde{v}(\mathrm{~N}-\mathrm{H})$ : $3454(\mathrm{~s}), 3271(\mathrm{~m}) ; \tilde{v}(\mathrm{C}=\mathrm{N}): 1618(\mathrm{~s}) ; \delta(\mathrm{N}-\mathrm{H})$, $v(\mathrm{C}=\mathrm{N}): \quad 1566(\mathrm{~m}) ; \quad \delta(\mathrm{C}-\mathrm{H}): \quad 769(\mathrm{w}), \quad 690(\mathrm{~m}), \quad 665(\mathrm{w}) ; \mathrm{HRESI}^{+}-\mathrm{MS}$ $\left(\mathrm{MeOH} / \mathrm{Me}_{2} \mathrm{SO} 1.00: 0.01, \mathrm{v} / \mathrm{v}\right): \mathrm{m} / \mathrm{z}$ calcd for $\left([\mathrm{M}+\mathrm{Na}]^{+}\right): 689.1448$; found: 689.1447; elemental analysis (\%) calcd for $\mathrm{C}_{16} \mathrm{H}_{32} \mathrm{~N}_{8} \mathrm{Cl}_{2} \mathrm{O}_{4} \mathrm{Pt}$ : C, 28.83 ; H, 4.84; N, 16.81; found: C, 28.74; H, 4.87; N, 16.90 .

6 (28.2 mg, $78 \%$ ): m.p. $143^{\circ} \mathrm{C}$ (decomp); ${ }^{1} \mathrm{H}$ NMR (400 MHz, $\mathrm{Me}_{2} \mathrm{SO}-$ $\left.d_{6}, 27^{\circ} \mathrm{C}\right): 8.11(\mathrm{~s}, \mathrm{br}, 2 \mathrm{H}, \mathrm{NH}), 7.07\left(\mathrm{~s}, \mathrm{br}, 4 \mathrm{H}, \mathrm{NH}_{2}\right), 4.00-3.97(\mathrm{~m}$, $\left.\left.8 \mathrm{H}, \mathrm{CH}_{2}\right), 3.57-3.54\left(\mathrm{~m}, 8 \mathrm{H}, \mathrm{CH}_{2}\right), 1.74\left(\mathrm{~s}, 18 \mathrm{H}, \mathrm{CH}_{3}\right) ;{ }^{13} \mathrm{C}^{1} \mathrm{H}\right\}$ NMR $\left(100 \mathrm{MHz}, \mathrm{Me}_{2} \mathrm{SO}-d_{6}, 27^{\circ} \mathrm{C}\right): 174.00(\mathrm{C}=\mathrm{NH}), 154.23(\mathrm{C}=\mathrm{N}), 65.91$ $\left(\mathrm{CH}_{2}\right), 45.89\left(\mathrm{CH}_{2}\right), 34.13\left(\mathrm{C}\left(\mathrm{CH}_{3}\right)_{3}\right), 25.03\left(\mathrm{CH}_{3}\right) ; \mathrm{IR}(\mathrm{KBr}$, selected bonds, $\left.\mathrm{cm}^{-1}\right)$ : $\tilde{v}(\mathrm{~N}-\mathrm{H}): 3461(\mathrm{~s}), 3346(\mathrm{~s}), 3228(\mathrm{~s}) ; \tilde{v}(\mathrm{C}-\mathrm{H}): 2854(\mathrm{w})$; $\tilde{v}(\mathrm{C}=\mathrm{N}): 1618(\mathrm{~s}) ; \delta(\mathrm{N}-\mathrm{H}), \tilde{v}(\mathrm{C}=\mathrm{N}): 1560(\mathrm{~m}) ; \delta(\mathrm{C}-\mathrm{H}):$ 995(w), 858(w), $757(\mathrm{~m}), 696(\mathrm{w}) ; \mathrm{HRESI}^{+}-\mathrm{MS}\left(\mathrm{MeOH} / \mathrm{Me}_{2} \mathrm{SO} 1.00: 0.01, \mathrm{v} / \mathrm{v}\right): \mathrm{m} / \mathrm{z}$ calcd for $\left([M+H]^{+}\right)$: 723.2256; found: 723.2239; elemental analysis (\%) calcd for $\mathrm{C}_{20} \mathrm{H}_{40} \mathrm{~N}_{8} \mathrm{Cl}_{2} \mathrm{O}_{4} \mathrm{Pt}$ : C, 33.24; $\mathrm{H}, 5.58 ; \mathrm{N}, 15.51$; found: $\mathrm{C}$, $33.74 ; \mathrm{H}, 5.87 ; \mathrm{N}, 15.90$.

7 (31.0 mg, $81 \%$ ): m.p. $156^{\circ} \mathrm{C}$ (decomp); ${ }^{1} \mathrm{H}$ NMR $\left(400 \mathrm{MHz}, \mathrm{Me}_{2} \mathrm{SO}-\right.$ $\left.d_{6}, 27^{\circ} \mathrm{C}\right): 8.24(\mathrm{~s}, \mathrm{br}, 2 \mathrm{H}, \mathrm{NH}), 7.84-7.82(\mathrm{~m}, 4 \mathrm{H}, \mathrm{Ph}), 7.75-7.72(\mathrm{~m}$, 2H, Ph), 7.61-7.59 (m, 4H, Ph), $5.57\left(\mathrm{~s}, \mathrm{br}, 4 \mathrm{H}, \mathrm{NH}_{2}\right), 4.10-4.07(\mathrm{~m}$, $\left.8 \mathrm{H}, \mathrm{CH}_{2}\right), 3.65-3.61\left(\mathrm{~m}, 8 \mathrm{H}, \mathrm{CH}_{2}\right) ;{ }^{13} \mathrm{C}\left\{{ }^{1} \mathrm{H}\right\}$ NMR $\left(100 \mathrm{MHz}, \mathrm{Me}_{2} \mathrm{SO}-d_{6}\right.$ $\left.27^{\circ} \mathrm{C}\right): 171.03(\mathrm{C}=\mathrm{NH}), 160.31(\mathrm{C}=\mathrm{N}), 138.57,136.59,133.82\left(\mathrm{CH}_{\mathrm{Ar}}\right)$, $116.22\left(\mathrm{C}_{\mathrm{Ar}}\right), 66.15\left(\mathrm{CH}_{2}\right), 47.50\left(\mathrm{CH}_{2}\right)$; IR $\left(\mathrm{KBr}\right.$, selected bonds, $\left.\mathrm{cm}^{-1}\right)$ : $\tilde{v}(\mathrm{~N}-\mathrm{H}): 3438(\mathrm{~s}), 3350(\mathrm{~s}), 3280(\mathrm{~m}) ; \tilde{v}(\mathrm{C}=\mathrm{N})$ and/or $\tilde{v}\left(\mathrm{C}=\mathrm{C}_{\mathrm{Ar}}\right): 1627(\mathrm{~s})$; $\delta(\mathrm{N}-\mathrm{H}), \tilde{v}(\mathrm{C}=\mathrm{N})$, and/or $\tilde{v}\left(\mathrm{C}=\mathrm{C}_{\mathrm{Ar}}\right): 1571(\mathrm{~m}) ; \delta(\mathrm{C}-\mathrm{H}): 713(\mathrm{~m}), 551(\mathrm{w})$; HRESI ${ }^{+}$-MS (MeOH/Me $\left./ \mathrm{MO}_{2} 1.00: 0.01, \mathrm{v} / \mathrm{v}\right): \mathrm{m} / \mathrm{z}$ calcd for $\left([\mathrm{M}+\mathrm{H}]^{+}\right)$: 763.1632; found: 763.1613; elemental analysis (\%) calcd for $\mathrm{C}_{24} \mathrm{H}_{32} \mathrm{~N}_{8} \mathrm{Cl}_{2} \mathrm{O}_{4} \mathrm{Pt}$ : C, 37.80; $\mathrm{H}, 4.23 ; \mathrm{N}, 14.69$; found: $\mathrm{C}, 37.78 ; \mathrm{H}$, 4.27; N, 14.90 .

8 (31.8 mg, 69\%): m.p. $144^{\circ} \mathrm{C}$ (decomp); ${ }^{1} \mathrm{H}$ NMR (400 MHz, $\mathrm{Me}_{2} \mathrm{SO}-$ $\left.d_{6}, 27^{\circ} \mathrm{C}\right): 8.30\left(\mathrm{~d}, 4 \mathrm{H}, \mathrm{CH}_{\mathrm{Ar}}\right), 8.08(\mathrm{~s}, 2 \mathrm{H}, \mathrm{NH}), 7.53-7.48(\mathrm{~m}, 4 \mathrm{H}$, $\left.\mathrm{CH}_{\mathrm{Ar}}\right), 5.22\left(\mathrm{~s}, 4 \mathrm{H}, \mathrm{NH}_{2}\right), 3.63-3.61\left(\mathrm{~m}, 8 \mathrm{H}, \mathrm{CH}_{2}\right), 3.18-3.15(\mathrm{~m}, 8 \mathrm{H}$, $\left.\mathrm{CH}_{2}\right) ;{ }^{13} \mathrm{C}\left\{{ }^{1} \mathrm{H}\right\} \quad \mathrm{NMR}\left(100 \mathrm{MHz}, \mathrm{Me}_{2} \mathrm{SO}-d_{6}, 27^{\circ} \mathrm{C}\right): 159.14 \quad(\mathrm{C}=\mathrm{NH})$, 132.74, 131.24, 130.82, $129.03\left(\mathrm{CH}_{\mathrm{Ar}}\right), 126.37\left(\mathrm{C}_{\mathrm{Ar}}\right), 65.91\left(\mathrm{CH}_{2}\right), 45.90$ $\left(\mathrm{CH}_{2}\right)$; IR ( $\mathrm{KBr}$, selected bonds, $\left.\mathrm{Cm}^{-1}\right)$ : $\tilde{v}(\mathrm{~N}-\mathrm{H}): 3438(\mathrm{~s}), 3350(\mathrm{~s}) ; \tilde{v}(\mathrm{C}=$ $\mathrm{N})$ and/or $\tilde{v}\left(\mathrm{C}=\mathrm{C}_{\mathrm{Ar}}\right)$ : $1668(\mathrm{~s}), 1627(\mathrm{~s}) ; \delta(\mathrm{N}-\mathrm{H}), \tilde{v}(\mathrm{C}=\mathrm{N})$, and/or $\tilde{v}(\mathrm{C}=$ $\left.\mathrm{C}_{\mathrm{Ar}}\right): 1571(\mathrm{~m}) ; \delta(\mathrm{C}-\mathrm{H}): 823(\mathrm{~m}), 781(\mathrm{w}) ; \mathrm{HRESI}^{+}-\mathrm{MS}\left(\mathrm{MeOH} / \mathrm{Me}_{2} \mathrm{SO}\right.$ $1.00: 0.01, \mathrm{v} / \mathrm{v}): \mathrm{m} / \mathrm{z}$ calcd for $\left([\mathrm{M}-\mathrm{Cl}]^{+}\right): 788.9752$; found: 788.9746; elemental analysis (\%) calcd for $\mathrm{C}_{24} \mathrm{H}_{30} \mathrm{~N}_{8} \mathrm{Br}_{2} \mathrm{Cl}_{2} \mathrm{O}_{4} \mathrm{Pt}$ : C, 31.32; $\mathrm{H}$, 3.29 ; N, 12.18; found: C, 31.34; H, 3.17; N, 12.51 . 
12 (24.3 mg, $73 \%$ ): m.p. $156{ }^{\circ} \mathrm{C}$ (decomp); ${ }^{1} \mathrm{H} \mathrm{NMR}(400 \mathrm{MHz}$, $\left.\mathrm{Me}_{2} \mathrm{SO}-d_{6}, 27^{\circ} \mathrm{C}\right): 8.03(\mathrm{~s}, 2 \mathrm{H}, \mathrm{NH}), 6.28\left(\mathrm{~s}, \mathrm{br}, 4 \mathrm{H}, \mathrm{NH}_{2}\right), 3.62-3.59$ $\left(\mathrm{m}, 8 \mathrm{H}, \mathrm{CH}_{2}\right), 3.20-3.17\left(\mathrm{~m}, 8 \mathrm{H}, \mathrm{CH}_{2}\right), 2.88\left(\mathrm{q}, 4 \mathrm{H}, \mathrm{CH}_{2}\right), 1.27(\mathrm{t}, 6 \mathrm{H}$, $\left.\mathrm{CH}_{3}\right) ;{ }^{13} \mathrm{C}\left\{{ }^{1} \mathrm{H}\right\}$ NMR $\left(100 \mathrm{MHz}, \mathrm{Me}_{2} \mathrm{SO}-d_{6}, 27^{\circ} \mathrm{C}\right): 173.38(\mathrm{C}=\mathrm{NH})$, $159.60(\mathrm{C}=\mathrm{N}), 66.00\left(\mathrm{CH}_{2}\right), 46.01\left(\mathrm{CH}_{2}\right), 26.43\left(\mathrm{CH}_{2}\right), 11.07\left(\mathrm{CH}_{3}\right)$; IR $\left(\mathrm{KBr}\right.$, selected bonds, $\left.\mathrm{cm}^{-1}\right): \tilde{v}(\mathrm{~N}-\mathrm{H}): 3448(\mathrm{~s}), 3238(\mathrm{~s}) ; \quad \tilde{v}(\mathrm{C}=\mathrm{N})$ : $1620(\mathrm{~s}) ; \delta(\mathrm{N}-\mathrm{H}), \tilde{v}(\mathrm{C}=\mathrm{N}): 1566(\mathrm{~m}) ; \delta(\mathrm{C}-\mathrm{H}): 887(\mathrm{~m}), 850(\mathrm{w}), 719(\mathrm{~m})$; HRESI ${ }^{+}$-MS $\left(\mathrm{MeOH} / \mathrm{Me}_{2} \mathrm{SO}\right.$ 1.00:0.01, v/v): $\mathrm{m} / z$ calcd for $\left([\mathrm{M}+\mathrm{Na}]^{+}\right)$: 689.1448; found: 689.1446; elemental analysis (\%) calcd for $\mathrm{C}_{16} \mathrm{H}_{32} \mathrm{~N}_{8} \mathrm{Cl}_{2} \mathrm{O}_{4} \mathrm{Pt}$ : C, 28.83; $\mathrm{H}, 4.84 ; \mathrm{N}, 16.81$; found: $\mathrm{C}, 28.74 ; \mathrm{H}$, $5.02 ; \mathrm{N}, 16.85$.

13 (32.2 mg, 89\%): m.p. $164^{\circ} \mathrm{C}$ (decomp); ${ }^{1} \mathrm{H} N M R \quad(400 \mathrm{MHz}$, $\left.\mathrm{Me}_{2} \mathrm{SO}-d_{6}, 27^{\circ} \mathrm{C}\right): 8.23(\mathrm{~s}, \mathrm{br}, 2 \mathrm{H}, \mathrm{NH}), 6.96\left(\mathrm{~s}, \mathrm{br}, 4 \mathrm{H}, \mathrm{NH}_{2}\right), 4.06-4.02$ $\left(\mathrm{m}, 8 \mathrm{H}, \mathrm{CH}_{2}\right), 3.63-3.60\left(\mathrm{~m}, 8 \mathrm{H}, \mathrm{CH}_{2}\right), 1.64\left(\mathrm{~s}, 18 \mathrm{H}, \mathrm{CH}_{3}\right) ;{ }^{13} \mathrm{C}\left\{{ }^{1} \mathrm{H}\right\}$ NMR $\left(100 \mathrm{MHz}, \mathrm{Me}_{2} \mathrm{SO}-d_{6}, 27^{\circ} \mathrm{C}\right): 168.89(\mathrm{C}=\mathrm{NH}), 151.74(\mathrm{C}=\mathrm{N})$, $64.38\left(\mathrm{CH}_{2}\right), 46.91\left(\mathrm{CH}_{2}\right), 29.40\left(\mathrm{C}\left(\mathrm{CH}_{3}\right)_{3}\right), 24.54\left(\mathrm{CH}_{3}\right)$; IR $(\mathrm{KBr}$, selected bonds, $\left.\mathrm{cm}^{-1}\right)$ : $\tilde{v}(\mathrm{~N}-\mathrm{H}): \quad 3589(\mathrm{~s}), \quad 3461(\mathrm{~s}), \quad 3355(\mathrm{~m}) ; \quad \tilde{v}(\mathrm{C}=\mathrm{N})$ : $1618(\mathrm{~s}) ; \delta(\mathrm{N}-\mathrm{H}), \tilde{v}(\mathrm{C}=\mathrm{N}): 1552(\mathrm{~m}) ; \delta(\mathrm{C}-\mathrm{H}): 862(\mathrm{w}), 721(\mathrm{~m}), 657(\mathrm{w})$; $\mathrm{HRESI}^{+}$-MS (MeOH/Me $\mathrm{SO}$ 1.00:0.01, v/v): $\mathrm{m} / \mathrm{z}$ calcd for $\left([\mathrm{M}+\mathrm{H}]^{+}\right)$: 723.2256; found: 723.2225; elemental analysis (\%) calcd for $\mathrm{C}_{20} \mathrm{H}_{40} \mathrm{~N}_{8} \mathrm{Cl}_{2} \mathrm{O}_{4} \mathrm{Pt}$ : C, 33.24; $\mathrm{H}, 5.58 ; \mathrm{N}, 15.51$, found: $\mathrm{C}, 33.19 ; \mathrm{H}, 5.67$; $\mathrm{N}, 15.50$.

14 (29.7 mg, 78\%): m.p. $158^{\circ} \mathrm{C}$ (decomp); ${ }^{1} \mathrm{H} \mathrm{NMR}(400 \mathrm{MHz}$, $\left.\mathrm{Me}_{2} \mathrm{SO}-d_{6}, 27^{\circ} \mathrm{C}\right): 8.63(\mathrm{~m}, 2 \mathrm{H}, \mathrm{Ph}), 8.19(\mathrm{~s}, \mathrm{br}, 2 \mathrm{H}, \mathrm{NH}), 7.69-7.66$ $(\mathrm{m}, 4 \mathrm{H}, \mathrm{Ph}), 7.34-7.30(\mathrm{~m}, 4 \mathrm{H}, \mathrm{Ph}), 6.54\left(\mathrm{~s}, \mathrm{br}, 4 \mathrm{H}, \mathrm{NH}_{2}\right), 3.81-3.78$ $\left.\left(\mathrm{m}, 8 \mathrm{H}, \mathrm{CH}_{2}\right), 3.22-3.19\left(\mathrm{~m}, 8 \mathrm{H}, \mathrm{CH}_{2}\right) ;{ }^{13} \mathrm{C}^{1} \mathrm{H}\right\} \quad \mathrm{NMR}(100 \mathrm{MHz}$, $\left.\mathrm{Me}_{2} \mathrm{SO}-d_{6}, 27^{\circ} \mathrm{C}\right): 166.74(C=\mathrm{NH}), 151.90(C=\mathrm{N}), 141.20,140.05$, $136.77\left(\mathrm{CH}_{\mathrm{Ar}}\right), 113.25\left(\mathrm{C}_{\mathrm{Ar}}\right), 67.00\left(\mathrm{CH}_{2}\right), 48.47\left(\mathrm{CH}_{2}\right)$; IR $(\mathrm{KBr}$, selected bonds, $\left.\mathrm{cm}^{-1}\right): \tilde{v}(\mathrm{~N}-\mathrm{H})$ : 3346(s), 3238(s); $\tilde{v}(\mathrm{C}=\mathrm{N})$ and/or $\tilde{v}\left(\mathrm{C}=\mathrm{C}_{\mathrm{Ar}}\right)$ : $1633(\mathrm{~s}) ; \delta(\mathrm{N}-\mathrm{H}), \tilde{v}(\mathrm{C}=\mathrm{N})$, and/or $\tilde{v}\left(\mathrm{C}=\mathrm{C}_{\mathrm{Ar}}\right): 1508(\mathrm{~m}), 1466(\mathrm{~m}) ; \delta(\mathrm{C}-$ $\mathrm{H}): 823(\mathrm{w}), 748(\mathrm{~m}), 665(\mathrm{w}) ; \mathrm{HRESI}^{+}$-MS $\left(\mathrm{MeOH} / \mathrm{Me}_{2} \mathrm{SO} 1.00: 0.01, \mathrm{v} /\right.$ v): $\mathrm{m} / \mathrm{z}$ calcd for $\left([\mathrm{M}+\mathrm{H}]^{+}\right)$: 763.1632; found: 763.1613 ; elemental analysis (\%) calcd for $\mathrm{C}_{24} \mathrm{H}_{32} \mathrm{~N}_{8} \mathrm{Cl}_{2} \mathrm{O}_{4} \mathrm{Pt}$ : C, 37.80; $\mathrm{H}, 4.23 ; \mathrm{N}, 14.69$; found: $\mathrm{C}, 37.82 ; \mathrm{H}, 4.28 ; \mathrm{N}, 14.77$.

\section{Acknowledgements}

This study is a combination of two projects focused on the reactivity of metal-activated nitriles (funded by Russian Science Foundation; grant 14-13-00060 for N.A.B.) and on novel polymer materials (funded by Russian Fund for Basic Research; grant 14-0300260-a for R.M.I.). M.Y.D. is much obliged to Saint Petersburg State University for a postdoctoral fellowship (12.50.1557.2013). Physicochemical studies were performed at the Center for Magnetic Resonance, Center for X-ray Diffraction Studies, Center for Chemical Analysis and Materials Research, and the Center for Thermogravimetric and Calorimetric Research (all belong to Saint Petersburg State University). The polymers for evaluation of catalytic activity were obtained from FSUE NIISK (Saint Petersburg, Russian Federation).

Keywords: cross-linking · hydroxyguanidines $\cdot$ hydrosilylation platinum complexes $\cdot$ polysiloxanes

[1] a) B. Marciniec, Hydrosilylation and Related Reactions of Silicon Compounds, Wiley-VCH Verlag GmbH, Weinheim, 2002, pp. 491-512; b) I. Ojima, Z. Li, J. Zhu, Recent Advances in Hydrosilylation and Related Reactions, Wiley, New York, 1998, pp. 1687-1792; c) A. K. Roy, Adv. Organomet. Chem. 2008, 55, 1-59; d) S. Sakaki, N. Mizoe, M. Sugimoto, Y. Musashi, Coord. Chem. Rev. 1999, 190-192, 933-960; e) M. Pagliaro, R. Ciri- minna, V. Pandarus, F. Beland, Eur. J. Org. Chem. 2013, 6227-6235; f) X. Zeng, Chem. Rev. 2013, 113,6864-6900; g) Y. Nakajima, S. Shimada, RSC Adv. 2015, 5, 20603-20616.

[2] D. Troegel, J. Stohrer, Coord. Chem. Rev. 2011, 255, 1440-1459.

[3] a) A. Pace, P. Pierro, Org. Biomol. Chem. 2009, 7, 4337-4348; b) I. Kownacki, B. Marciniec, K. Szubert, M. Kubicki, M. Jankowska, H. Steinberger, S. Rubinsztajn, Appl. Catal. A 2010, 380, 105-112.

[4] B. Marciniec, H. Maciejewski, Coord. Chem. Rev. 2001, 223, 301-335.

[5] A. V. Gorshkov, Kauch. Rezina 1989, 6, 36-42; Chem. Abs. 1990, CAN 112:8578.

[6] V. P. Boyarskiy, K. V. Luzyanin, V. Y. Kukushkin, Coord. Chem. Rev. 2012, 256, 2029-2056.

[7] B. G. M. Rocha, E. A. Valishina, R. S. Chay, M. F. C. Guedes da Silva, T. M. Buslaeva, A. J. L. Pombeiro, V. Y. Kukushkin, K. V. Luzyanin, J. Catal. 2014, $309,79-86$

[8] a) K. V. Luzyanin, A. G. Tskhovrebov, M. C. Carias, M. F. C. Guedes da Silva, A. J. L. Pombeiro, V. Y. Kukushkin, Organometallics 2009, 28, 6559-6566; b) R. S. Chay, K. V. Luzyanin, V. Y. Kukushkin, M. F. C. Guedes da Silva, A. J. L. Pombeiro, Organometallics 2012, 31, 2379-2387; c) M. A. Kinzhalov, K. V. Luzyanin, V. P. Boyarskiy, M. Haukka, V. Y. Kukushkin, Organometallics 2013, 32, 5212-5223; d) E. A. Valishina, M. F. C. Guedes da Silva, M. A. Kinzhalov, S. A. Timofeeva, T. M. Buslaeva, M. Haukka, A. J. L. Pombeiro, V. P. Boyarskiy, V. Y. Kukushkin, K. V. Luzyanin, J. Mol. Catal. A: Chem. 2014, 395, 162-171; e) S. A. Timofeeva, M. A. Kinzhalov, E. A. Valishina, K. V. Luzyanin, V. P. Boyarskiy, T. M. Buslaeva, M. Haukka, V. Y. Kukushkin, J. Catal. 2015, 329, 449-456.

[9] a) V. Y. Kukushkin, T. B. Pakhomova, Y. N. Kukushkin, R. Herrmann, G. Wagner, A. J. L. Pombeiro, Inorg. Chem. 1998, 37, 6511-6517; b) N. A. Bokach, V. Y. Kukushkin, Russ. Chem. Bull. 2005, 74, 153-170; c) A. J. L. Pombeiro, V.Y. Kukushkin, Comprehensive Coordination Chemistry, 2nd ed., Vol. 1, Elsevier, Amsterdam, New York, 2004, pp. 585-594.

[10] M. N. Kopylovich, V. Y. Kukushkin, M. F. C. Guedes da Silva, M. Haukka, J. J. R. Fraústo da Silva, A. J. L. Pombeiro, J. Chem. Soc. Perkin Trans. 1 2001, 1569-1573.

[11] D. S. Bolotin, N. A. Bokach, A. S. Kritchenkov, M. Haukka, V. Yu. Kukushkin, Inorg. Chem. 2013, 52, 6378-6389.

[12] M. N. Kopylovich, A. J. L. Pombeiro, A. Fischer, L. Kloo, V. Y. Kukushkin, Inorg. Chem. 2003, 42, 7239-7248.

[13] a) M. N. Kopylovich, J. Lasri, M. F. C. Guedes da Silva, A. J. L. Pombeiro, Eur. J. Inorg. Chem. 2011, 377-383; b) M. N. Kopylovich, J. Lasri, M. F. C. Guedes da Silva, A. J. L. Pombeiro, Dalton Trans. 2009, 3074-3084; c) M. N. Kopylovich, M. Haukka, A. M. Kirillov, V. Y. Kukushkin, A. J. L. Pombeiro, Chem. Eur. J. 2007, 13, 786-791.

[14] a) M. N. Kopylovich, V. Y. Kukushkin, M. Haukka, J. J. R. Frausto da Silva, A. J. L. Pombeiro, Inorg. Chem. 2002, 41, 4798-4804; b) E. S. Kim, H. S. Lee, S. H. Kim, J. N. Kim, Tetrahedron Lett. 2010, 51, 1589-1591 c) A. J. L. Pombeiro, V. Yu. Kukushkin, M. N. Kopylovich, J. J. R. Frausto da Silva, Catalyst and synthetic process for carboxamides by nitrile hydrolysis, Patent PT 102618, 2001; d) X.-Y. Ma, Y. He, Y.-L. Hu, M. Lu, Tetrahedron Lett. 2012, 53, 449-452; e) M. Kim, J. Lee, H.-Y. Lee, S. Chang, Adv. Synth. Catal. 2009, 351, 1807-1812.

[15] a) K. F. Konidaris, C. D. Polyzou, G. E. Kostakis, A. J. Tasiopoulos, O. Roubeau, S. J. Teat, E. Manessi-Zoupa, A. K. Powell, S. P. Perlepes, Dalton Trans. 2012, 41, 2862-2865; b) S. K. Singh, S. Sharma, S. D. Dwivedi, R.Q. Zou, Q. Xu, D. S. Pandey, Inorg. Chem. 2008, 47, 11942-11949.

[16] a) M. N. Kopylovich, V. Y. Kukushkin, M. Haukka, K. V. Luzyanin, A. J. L. Pombeiro, J. Am. Chem. Soc. 2004, 126, 15040-15041; b) K. V. Luzyanin, V. Y. Kukushkin, M. N. Kopylovich, A. A. Nazarov, M. Galanski, A. J. L. Pombeiro, Adv. Synth. Catal. 2008, 350, 135-142.

[17] D. S. Bolotin, K. I. Kulish, N. A. Bokach, G. L. Starova, V. V. Gurzhiy, V. Y. Kukushkin, Inorg. Chem. 2014, 53, 10312-10324.

[18] M. Y. Demakova, D. S. Bolotin, N. A. Bokach, G. L. Starova, V. Y. Kukushkin, Inorg. Chim. Acta 2015, 425, 114-117.

[19] D. J. Aitken, A. Albinati, A. Gautier, H.-P. Husson, G. Morgant, D. NguyenHuy, J. Kozelka, P. Lemoine, S. Ongeri, S. Rizzato, B. Viossat, Eur. J. Inorg. Chem. 2007, 3327-3334.

[20] C. M. P. Ferreira, M. F. C. Guedes da Silva, J. J. R. Frausto da Silva, A. J. L. Pombeiro, V. Yu. Kukushkin, R. A. Michelin, Inorg. Chem. 2001, 40, 11341142.

[21] a) J. Lasri, M. A. J. Charmier, M. F. C. Guedes da Silva, A. J. L. Pombeiro, Dalton Trans. 2006, 5062-5067; b) J. Lasri, M. F. C. Guedes da Silva, 
M. A. J. Charmier, A. J. L. Pombeiro, Eur. J. Inorg. Chem. 2008, 3668 3677.

[22] D. S. Bolotin, N. A. Bokach, M. Haukka, V. Yu. Kukushkin, Inorg. Chem. 2012, 51, 5950-5964.

[23] a) V. P. Boyarskiy, N. A. Bokach, K. V. Luzyanin, V. Y. Kukushkin, Chem. Rev. 2015, 115, 2698-2779; b) V. P. Boyarskiy, K. V. Luzyanin, V. Y. Kukushkin Palladium-(acyclic diaminocarbene) Species as Alternative to Palladium(nitrogen heterocyclic carbenes) in Cross-Coupling Catalysis, John Wiley \& Sons, Inc., Hoboken, NJ, 2014, pp. 145-155.

[24] E. Delebecq, N. Hermeline, A. Flers, F. Ganachaud, ACS Appl. Mater. Interfaces 2012, 4, 3353-3363.

[25] D. S. Bolotin, N. A. Bokach, M. Haukka, V. Y. Kukushkin, ChemPlusChem 2012, 77, $31-40$.

[26] a) A. A. H. Ahmad Fuaad, F. Azmi, M. Skwarczynski, I. Toth, Molecules 2013, 18, 13148-13174; b) J. M. Aizpurua, R. M. Fratila, Z. Monasterio, N. Perez-Esnaola, E. Andreieff, A. Irastorza, M. Sagartzazu-Aizpurua, New J. Chem. 2014, 38, 474-480; c) P. K. Avti, D. Maysinger, A. Kakkar, Molecules 2013, 18, 9531-9549; d) M. M. Heravi, H. Hamidi, V. Zadsirjan, Curr. Org. Synth. 2014, 11, 647-675; e) L. Mirfeizi, L. Campbell-Verduyn, R. A. Dierckx, B. L. Feringa, P. H. Elsinga, Curr. Org. Chem. 2013, 17 2108-2118; f) P. Sapkale, M. Sahu, M. Chaudhari, P. R. Patil, Int. J. Pharm. Pharm. Sci. 2014, 6, 99-103; g) E. M. Scanlan, V. Corce, A. Malone, Molecules 2014, 19, 19137-19151; h) W. Tang, M. L. Becker, Chem. Soc. Rev. 2014, 43, 7013-7039; i) U. Tunca, J. Polym. Sci. Part A 2014, 52, $3147-$ 3165 ; j) S. Ulrich, D. Boturyn, A. Marra, O. Renaudet, P. Dumy, Chem. Eur. J. 2014, 20, 34-41; k) W. Xi, T. F. Scott, C. J. Kloxin, C. N. Bowman, Adv. Funct. Mater. 2014, 24, 2572-2590; I) Y. Yuan, G. Liang, Org. Biomol. Chem. 2014, 12, 865-871.
[27] a) R. A. Kunetskiy, S. M. Polyakova, J. Vavrík, I. Císaróva, J. Saame, E. R. Nerut, I. Koppel, I. A. Koppel, A. Kütt, I. Leito, I. M. Lyapkalo, Chem. Eur. J. 2012, 18, 3621-3630; b) U. Wild, C. Neuhäuser, S. Wiesner, E. Kaifer, H. Wadepohl, H.-J. Himmel, Chem. Eur. J. 2014, 20, 5914-5925; c) C. Trumm, O. Hübner, P. Walter, S. Leingang, U. Wild, E. Kaifer, B. Eberle, H.J. Himmel, Eur. J. Inorg. Chem. 2014, 6039-6050; d) C. H. Tan, M. Coles, Aust. J. Chem. 2014, 67, 963-964; e) M. P. Coles, Dalton Trans. 2006 985-1001; f) P. J. Bailey, S. Pace, Coord. Chem. Rev. 2001, 214, 91-141.

[28] a) E. E. Finney, R. G. Finke, Inorg. Chim. Acta 2006, 359, 2879-2887; b) L. N. Lewis, J. Stein, Y. Gao, R. E. Colborn, G. Hutchins, Platinum Met. Rev. 1997, 41, 66-75.

[29] Y. N. Kukushkin, T. B. Pakhomova, Zh. Obshch. Khim. 1995, 65, 330.

[30] P. Svensson, K. Loevqvist, V. Y. Kukushkin, A. Oskarsson, Acta Chem. Scand. 1995, 49, $72-75$.

[31] R. Cini, F. P. Fanizzi, F. P. Intini, L. Maresca, G. Natile, J. Am. Chem. Soc. 1993, 115, 5123-5131.

[32] Q. Jia, T. Cai, M. Huang, H. Li, M. Xian, T. L. Poulos, P. G. Wang, J. Med. Chem. 2003, 46, $2271-2274$

[33] G. M. Sheldrick, Acta Crystallogr. Sect. A 2008, 64, 112-122.

[34] O. V. Dolomanov, L. J. Bourhis, R. J. Gildea, J. A. K. Howard, H. Puschmann, J. Appl. Crystallogr. 2009, 42, 339-341.

[35] CrysAlisPro, 1.171.36.20, Agilent Technologies, 27-06-2012, 2012.

Manuscript received: July 20, 2015

Accepted Article published: September 4, 2015

Final Article published: September 17, 2015 